\title{
Arthropoda Permukaan Tanah : Kelimpahan, Keanekaragaman, Komposisi dan Hubungannya dengan Fase Pertumbuhan Tanaman pada Ekosistem Padi Hitam Berpupuk Organik
}

\author{
Vira Kusuma Dewi ${ }^{1}$, Rizky Fauzi ${ }^{2}$, Santika Sari ${ }^{3}$, Sri Hartati ${ }^{1}$, Siska Rasiska ${ }^{1}$, Yongki Umam Sandi ${ }^{2}$, \\ Dwi Harya Yudistira ${ }^{2}$ \\ ${ }^{1}$ Departemen Hama dan Penyakit Tumbuhan, Fakultas Pertanian, Universitas Padjadjaran \\ ${ }^{2}$ Program Studi Agroteknologi, Fakultas Pertanian, Universitas Padjadjaran \\ ${ }^{3}$ Departemen Budidaya Pertanian, Fakultas Pertanian Universitas Padjadjaran \\ Jl. Raya Bandung-Sumedang KM-21, Jatinangor 45363 \\ *Alamat korespondensi: vira.kusuma.dewi@unpad.ac.id
}

\section{ABSTRACT \\ Ground arthropods : Abundance, diversity, composition and their relationship to the plant growth phase in black paddy ecosystem using organic fertilizer}

Arthropod is important component in the soil ecosystem. They have a very important role in organic matter decomposition, soil aeration and nutrient cycling. This study was conducted to know the effect of neem cake and siam weed compost on abundance, diversity, composition of ground arthropods and their relationship to the plant growth phase in black rice ecosystem. The experiment was carried out in paddy field at Cinenggang, Cileles Village, Jatinangor from April to November 2018. The experimental method was used a Randomized Block Design and followed by five treatment (neem cake, siam weed compost, cow manure, synthetic fertilizer and control) with six replications. The result showed that total number of ground arthropods family were caught at study site as mush as nine families that are famili Carabidae, Curculionidae, Staphylinidae, Formicidae, Acrididae, Gryllidae, Gryllotalpidae, Nepidae, and Lycosidae. The family (Carabidae and Formicidae) were the most abundant in all treatments as follow control treatment (117; 31 individuals), neem cake (142; 159 individuals). siam weed compost (160;98 individuals), cow manure (102; 74 individuals), and NPK (93; 70 individuals). The result also showed that the effect of neem cake and siam weed compost were significantly different in abundance of carnivore (predator) but there was no difference in herbivore. Furthermore, based on diversity index indicated that ground arthropod in all treatments were moderate $(1,470 ; 1,310 ; 1,377 ; 1,585 ; 1,638)$. In addition, the total abundance of ground arthropod in neem cake and siam weed compost treatments on vegetative phase were higher than cow manure, NPK and control (without fertilizer) treatments. However, the total abundance of ground arthropod on generative phase was higher in cow manure treatment if compared with other treatments.

Keywords: Carnivorous, Herbivores, Neem cake, Plant phase, Siam weed

\begin{abstract}
ABSTRAK
Arthropoda permukaan tanah merupakan bagian penting dari suatu ekosistem di dalam tanah yang berperan dalam proses dekomposisi, aerasi dan siklus nutrisi. Tujuan penelitian adalah mengetahui pengaruh pupuk organik asal ampas bungkil mimba dan gulma siam terhadap kelimpahan, keanekaragaman dan komposisi arthropoda permukaan tanah dan hubungannya dengan fase pertumbuhan tanaman pada ekosistem sawah padi hitam. Percobaan dilaksanakan di Cinenggang, Desa Cileles, Kecamatan Jatinangor, Kabupaten Sumedang sejak bulan April - November 2018. Penelitian dilakukan dengan metode eksperimen menggunakan Rancangan Acak Kelompok (RAK) terdiri dari lima perlakuan yaitu kontrol (tanpa pupuk), pupuk ampas bungkil mimba, kompos gulma siam, pupuk kohe sapi, dan NPK yang diulang sebanyak enam kali. Berdasarkan hasil penelitian diperoleh sembilan famili arthropoda permukaan tanah yang terdiri dari famili Carabidae, Curculionidae, Staphylinidae, Formicidae, Acrididae, Gryllidae, Gryllotalpidae, Nepidae, dan Lycosidae. Pada semua perlakuan,
\end{abstract}


kelimpahan arthropoda permukaan tanah yang mendominasi dari famili (Carabidae, Formicidae) yaitu perlakuan kontrol (117; 31 individu), pupuk ampas bungkil mimba (142; 159 individu), kompos gulma siam (160; 98 individu), pupuk kohe sapi (102; 74 individu) dan pupuk NPK (93; 70 individu). Hasil penelitian juga menunjukkan bahwa perlakuan pupuk ampas bungkil mimba dan kompos gulma siam memperlihatkan kelimpahan karnivor tertinggi, namun tidak berbeda nyata pada herbivor. Keanekaragaman arthropoda permukaan tanah pada semua perlakuan (kontrol, pupuk ampas bungkil mimba, kompos gulma siam, pupuk kohe sapi, pupuk NPK) memiliki nilai indeks keragaman sedang $(1,470 ; 1,310 ; 1,377 ; 1,585 ; 1,638)$. Selanjutnya, perlakuan ampas bungkil mimba dan kompos gulma siam menunjukkan total arthropoda permukaan tanah tertinggi pada fase vegetatif bila dibandingkan dengan perlakuan pupuk kohe sapi, NPK dan kontrol. Namun pada fase generatif, perlakuan pupuk kohe sapi yang memperlihatkan total arthropoda permukaan tertinggi dibandingkan perlakuan lainnya.

Kata kunci: Ampas bungkil mimba, Fase pertumbuhan tanaman padi, Gulma siam, Herbivor, Karnivor

\section{PENDAHULUAN}

Padi hitam (Oryza sativa L. var. indica) adalah padi lokal yang memiliki karakteristik produksi antosianin dengan intensitas tinggi sehingga warna padi menjadi ungu pekat hingga hitam. Padi hitam di kalangan masyarakat semakin popular dan banyak dikonsumsi (Kristamtini \& Purwaningsih, 2009). Akan tetapi, padi lokal memiliki beberapa kelemahan yaitu berumur panjang dan berdaya hasil rendah (Nurnayetti \& Atman, 2013). Oleh karena itu, umur panen padi hitam yang panjang dan produktifitas rendah merupakan faktor pembatas yang menyebabkan minat petani semakin rendah untuk menanamnya. Berdasarkan kondisi tersebut, maka diperlukan upaya dalam mendukung peningkatan produktivitas padi hitam.

Upaya peningkatan produksi beras salah satunya sering ditekankan pada penggunaan pupuk sintetik secara terus menerus sehingga kadang berdampak negatif terhadap lingkungan bila tidak digunakan secara bijaksana. Adapun penggunaan bahan kimia sintetik yang berlebihan dapat Menurut Samudra dkk., (2013) kelimpahan, keankeragaman dan komposisi arthropoda tanah dapat dijadikan ukuran dalam menilai keadaan atau indikator suatu ekosistem. Menurut Hadi \& Aminah (2015) jumlah individu arthropoda tanah pada sawah organik lebih tinggi yaitu 297 ekor/musim tanam, bila dibandingkan dengan jumlah individu arthropoda tanah pada sawah anorganik sebanyak 236 individu/musim tanam. Penelitian Witriyanto dkk., (2015) juga menunjukkan bahwa data kelimpahan arthropoda tanah di lahan persawahan padi organik lebih tinggi sebanyak 297 individu dibandingkan dengan lahan anorganik sebanyak 236 individu. Oleh menimbulkan pencemaran tanah pada lahan pertanian (Adriyani, 2006) sehingga mampu menurunkan kesuburan tanah dan keanekaragaman arthropoda tanah yang dapat mempengaruhi keseimbangan ekosistem sawah (Lestari \& Puji, 2009).

Tanah merupakan habitat dari berbagai organisme misalnya arthropoda, bakteri, jamur, nematoda, dan cacing tanah (Sofia, 2001; Jeffrey et al., 2011) yang memiliki peran penting dalam dekomposisi bahan organik tanah untuk penyediaan unsur hara bagi tanaman serta mendukung berlangsungnya rantai makanan dalam tanah (Bonkowski et al., 2000; Gardi \& Jeffrey, 2009; Kilowasid et al., 2013). Arthropoda tanah di ekosistem sawah merupakan arthropoda yang hidup dan aktif di dalam atau permukaan tanah dan mempunyai peranan penting dalam proses dekomposisi bahan organik tanah dan aktivitas lainnya. Arthropoda memakan material hayati baik sebagai herbivor maupun sebagai predator yang kemudian akan dikeluarkan dalam bentuk feses yang bermanfaat setelah terdekomposisi (Arief, 2001). karena itu, upaya peningkatan keanekeragaman hayati dapat membawa manfaat baik secara ekologi maupun ekonomi.

Salah satu strategi dalam peningkatan produksi tanaman yang ramah bagi lingkungan adalah pemupukan dan pengelolaan organisme pengganggu tanaman (OPT) yang tepat, di mana budidaya tanaman tidak membutuhkan pupuk sintetik yang berlebihan sehingga pengelolaan padi dapat dilakukan secara organik. Menurut Mayrowani (2012), pertanian organik merupakan kegiatan pertanian yang dalam penerapannya mengandalkan bahan-bahan alami tanpa menggunakan bahan- 
bahan kimia sintetis. Adapun tujuan pertanian organik yaitu menyediakan produk-produk pertanian atau bahan pangan yang aman bagi kesehatan produsen dan konsumennya serta tidak merusak lingkungan

Pemanfaatan bahan organik sebagai pupuk merupakan salah satu upaya dalam mendukung pertanian organik (Kardinan, 2011). Aplikasi bahan organik sebagai pupuk dapat meningkatkan kandungan unsur hara, fisik dan kimia tanah (Widowati, 2009) serta aktivitas organisme tanah (Leszczynska \& Malina, 2011). Adapun beberapa alternatif bahan tanaman yang dapat digunakan sebagai pupuk organik yaitu gulma siam (Choromolaena odonata(L.) R.M.King \& H.Rob.) dan ampas bungkil mimba (Azadirachta indica A.Juss).

Gulma siam adalah sejenis tumbuhan yang hidup liar di lahan kering dan banyak dijumpai pada lahan-lahan terbuka ataupun lahan marjinal. Gulma siam mengandung unsur hara yaitu kandungan karbon, kalsium, magnesium, kalium dan nitrogen yang lebih tinggi bila dibandingkan dengan pupuk kandang sapi (Dewi dkk., 2018; Suharjo \& Aeny, 2011). Penelitian Dewi dkk. (2018) juga melaporkan bahwa pertumbuhan tanaman cabai yang diberi perlakuan pupuk gulam siam tidak berbeda nyata dengan tanaman cabai yang diberi perlakuan pupuk sintetis NPK dan pupuk kandang. Hal ini menunjukkan bahwa gulma siam berpotensi digunakan sebagai alternatif pupuk organik.

Bahan organik lainnya adalah ampas bungkil mimba yang memiliki kandungan bahan aktif yaitu azadirachtin, minyak gliserida, polifenol, acetiloksifuranil dekahidrotetrametil acid, ksosiklopentanatofiliran, asetat keton, monoterpen, dan heksahidrosotetrametil (Nurindah, 2012). Menurut Setiawan \& Nandini (2013) ampas bungkil mimba berpotensi sangat baik sebagai bahan pembuatan pupuk dan pemulsaan. Selain itu, ampas bungkil mimba ini juga masih mengandung bahan aktif pestisida nabati yang bermanfaat mengendalikan organisme pengganggu tumbuhan (OPT) yang berada di dalam tanah, sehingga memiliki dua fungsi ganda yaitu sebagai pupuk organik dan pestisida (Zachariades et al., 2009). emanfaatan bahan organik gulma siam dan ampas bungkil mimba berpotensi sebagai pupuk organik, namun informasi terkait manfaat dan pengaruhnya terhadap diversitas arthropoda permukaan tanah sawah masih terbatas, sehingga perlu dilakukan kajian terkait pengaruh pupuk organik gulma dan ampas bungkil mimba terhadap komposisi, keanekaragaman, arthropoda permukaan tanah dan hubungannya dengan performa tanaman pada ekosistem sawah padi hitam.

\section{BAHAN DAN METODE}

Penelitian dilaksanakan di Cinenggang, Desa Cileles, Kecamatan Jatinangor, Kabupaten Sumedang, Jawa Barat dengan ketinggian \pm 765 mdpl. Identifikasi arthropoda permukaan tanah dilakukan di Laboratorium Hama Tanaman, Departemen Hama dan Penyakit Tumbuhan. Penelitian dilaksanakan dari bulan April-November 2018.

Penelitian menggunakan metode eksperimen dengan Rancangan Acak Kelompok (RAK). Jumlah perlakuan pada penelitian terdiri atas 5 taraf perlakuan dengan 6 kali ulangan. Perlakuan pada penelitian ini terdiri atas kontrol (tanpa perlakuan), pupuk ampas bungkil mimba (12 kg/plot), kompos gulma siam (12 kg/plot), pupuk kohe sapi (12 $\mathrm{kg} / \mathrm{plot})$ dan NPK Mutiara (180 g/plot).

\section{Persiapan pupuk ampas bungkil mimba}

Tahap awal yang dilakukan yaitu mengumpulkan material ampas bungkil mimba hasil proses pengepresan yang diperoleh dari Pusat Studi Pengembangan Produk dan Kemitraan, Departemen Hama dan Penyakit Tumbuhan, Fakultas Pertanian, Universitas Padjadjaran. Tahap berikutnya, ampas bungkil mimba dikeringanginkan selama 3 hari namun tidak langsung di bawah terik sinar matahari, agar terhindar dari jamur. Selanjutnya, ampas bungkil mimba ditimbang sesuai keperluan yang dibutuhkan.

\section{Persiapan kompos gulma siam}

Proses pembuatan pupuk gulma siam berlangsung selama 4 minggu. Adapun tahap pertama yang dilakukan adalah mengumpulkan gulma siam dan mencacahnya hingga halus. Selanjutnya, gulma siam yang telah selesai dicacah ditambahkan air dan diberikan bio-aktivator pengomposan (Stardeck) sebanyak 6,25 g untuk setiap $25 \mathrm{~kg}$ gulma siam dan diaduk hingga tercampur rata. Setelah itu, timbunan gulma siam disimpan dalam kotak kayu berukuran 2 $\mathrm{m}$ x $1 \mathrm{~m}$ x $1 \mathrm{~m}$. Selama proses pengomposan, setiap satu minggu sekali diberikan gula pasir sebanyak \pm 10 g untuk memberikan nutrisi bagi dekomposer yang digunakan dan dilakukan pembalikan. Apabila bahan organik telah mengalami perubahan warna menjadi hitam serta teksturnya seperti remahan maka menandakan proses pengomposan telah matang dan berhasil sehingga siap digunakan. 


\section{Persiapan pengolahan lahan}

Pada tahap awal pengolahan dilakukan pembajakan tanah sawah dengan tujuan membuat lapisan tanah yang berada di bawah terbalik keatas sehingga aerasi tanah dapat optimal. Tahap selanjutnya dilakukan pengairan tanah sawah selama seminggu dan dilakukan pengolahan tanah sawah kembali. Selanjutnya, pada lahan sawah dibuat 30 petakan atau plot dengan ukuran masing-masing petak sebesar $3 \mathrm{~m} \times 4 \mathrm{~m}$. Pada setiap petak perlakuan dibuat saluran inlet-outlet untuk mengurangi pergerakan arthropoda atau organisme untuk berpindah ke perlakuan yang berbeda serta meminimalisasi bercampurnya pengaruh dari pupuk yang digunakan antar petak. Adapun setiap petak perlakuan dipisahkan dengan guludan berjarak 50 $\mathrm{cm}$.

\section{Persiapan benih}

Pada tahap awal persemaian, benih diseleksi dengan cara merendamnya menggunakan air yang mengandung garam agar dapat diperoleh benih yang bernas. Benih padi hitam yang baik akan tenggalam dalam air sedangkan benih padi hitam yang tidak baik akan mengapung di permukaan air. Selanjutnya, benih yang telah terseleksi, direndam selama kurang lebih $2 \times 24$ jam dengan air bersih. Tahap berikutnya, benih ditiriskan selama 24 jam dan digunakan untuk penyemaian. Penyemaian benih padi hitam dilakukan pada baki yang berisi media tanam dengan campuran pupuk kandang/bokashi dan tanah bertekstur remah (1:1). Selanjutnya dilakukan penyiraman 2 kali sehari. Pada umur semaian $\pm 15-20$ hari, maka tanaman sudah siap pindah tanam.

\section{Penanaman}

Penanaman bibit padi dilakukan pada lahan sawah di areal penelitian Fakultas Pertanian Universitas Padjadjaran. Jarak tanam yang digunakan yaitu $30 \mathrm{~cm}$ x $16 \mathrm{~cm}$ (Dewi et al., 2017). Penanaman menggunakan sistem tanam tunggal yaitu menanam satu bibit tiap lubang tanam sehingga pada tiap petak perlakuan diperoleh sekitar 266 tanaman. Bibit yang digunakan ditanam dangkal dengan perakaran horizontal seperti huruf L agar bibit tidak memerlukan energi besar dalam memulai pertumbuhan kembali.

\section{Pemeliharaan tanaman}

Pemeliharaan tanaman meliputi pengairan dan penyiangan gulma. Penyiangan gulma dilakukan secara manual sebanyak 6 kali yaitu dengan mencabut gulma yang tumbuh di sekitar pertanaman secara langsung. Penyiangan gulma dimulai pada 1 minggu setelah tanam (mst) dengan rentang penyiangan 7-10 hari.

Aplikasi pupuk yang digunakan pada masing masing petak perlakuan diberikan sesuai perhitungan dan dilakukan dengan cara ditabur pada petak perlakuan. Aplikasi pupuk organik dilakukan 1 minggu sebelum tanam, sedangkan pupuk NPK diaplikasikan 1 minggu setelah tanam (mst). Terkait pengelolaan air, pada saat padi dalam fase vegetatif (belum keluar malai/tempat keluarnya bunga padi) dalam kondisi macak-macak. Setelah padi berumur 25-30 hari maka lahan mulai digenangi hingga setinggi $5-10 \mathrm{~cm}$. Pada saat anakan maksimum berumur 47-55 hari setelah tanam, lahan dalam dikeringkan selama 7-10 hari. Setelah 7-10 hari dikeringkan, kondisi lahan kembali dibasahi (macakmacak) selama masa pertumbuhan malai, bulir, dan pengisian bulir hingga bernas. Selanjutnya lahan dikeringkan kembali hingga saatnya panen.

\section{Tahap pengamatan}

Pengamatan arthropoda permukaan tanah dan performa tanaman dilakukan secara reguler mulai dari fase vegetatif sampai fase generatif yaitu (3 mst (minggu setelah tanam), $5 \mathrm{mst}, 7 \mathrm{mst}, 9 \mathrm{mst}, 11$ $\mathrm{mst}, 13 \mathrm{mst}$, dan $15 \mathrm{mst}$ ). Pengambilan sampel arthropoda permukaan tanah dilakukan dengan menggunakan pitfall trap. Arthropoda permukaan tanah yang diamati yaitu makroarthropoda tanah (mempunyai ukuran $>2 \mathrm{~mm}$ )

\section{Pengambilan sampel arthropoda permukaan tanah}

Pengambilan sampel arthropoda permukaan tanah dilakukan dengan menggunakan cup plastik sebagai perangkap pitfall trap. Pitfall trap berukuran (diameter $10 \mathrm{~cm}$, tinggi $15 \mathrm{~cm}$ ) dipasang pada bagian kanan dan kiri petak perlakuan dengan jarak antar pitfall trap sejauh $50 \mathrm{~cm}$, maka dalam satu petakan terdapat lima pitfall trap. Perangkap diisi dengan air sebanyak 1/4 dari volume cup plastik. Pengamatan dengan menggunakan pitfall dilakukan pada (3 mst, 5 mst, $7 \mathrm{mst}, 9 \mathrm{mst}, 11 \mathrm{mst}, 13 \mathrm{mst}$, dan $15 \mathrm{mst}$ ). Adapun, hasil arthropoda permukaan tanah yang terperangkap dimasukkan kedalam botol koleksi dengan alkohol $70 \%$ dan dilakukan identifikasi di laboratorium dengan menggunakan panduan buku identifikasi Borror et al. (1996) dan Bolton et al. (1996).

\section{Pengamatan performa tanaman padi}

Parameter pengamatan untuk tanaman padi adalah tinggi tanaman, $S P A D$ value, dan jumlah 
anakan. Jumlah tanaman yang diukur sebanyak 10 tanaman untuk tiap petak perlakuan. Pengamatan dilakukan pada (3 mst, 6 mst, 9 mst, 12 mst, dan 15 mst).

\section{Analisis data}

Keanekaragaman arthropoda permukaan tanah dihitung dengan menggunakan rumus Indeks diversitas Shannon-Wiener (Krebs, 1985) :

$\mathrm{H}^{\prime}=-\sum[(\mathrm{ni} / \mathrm{N}) \ln (\mathrm{ni} / \mathrm{N})]$

Keterangan:

$\mathrm{H}^{\prime}$ = indeks keragaman

$\mathrm{ni}=$ jumlah individu jenis ke-i

$\mathrm{N}$ = jumlah total individu yang ditemukan

Nilai H' berkisar antara :

$\mathrm{H}^{\prime} \leq 1$ : Keanekaragaman Rendah

$1<\mathrm{H}^{\prime} \leq 3 \quad:$ Keanekaragaman Sedang

H'> 3 : Keanekaragaman Tinggi Indeks dominansi ditentukan dengan indeks dominansi Simpson (Ludwig \& Reynolds, 1988) dengan menggunakan rumus:

\section{$\mathrm{C}=\Sigma(\mathrm{ni} / \mathrm{N})^{2}$}

Keterangan:

$\mathrm{C}=$ indeks dominansi Simpson

$\mathrm{ni}=$ jumlah individu suatu jenis

$\mathrm{N}=$ jumlah individu dari seluruh jenis

Kriteria indeks dominansi :

$\mathrm{C}<1$ maka spesies serangganya beranekaragam $\mathrm{C}=1$ maka spesies serangganya tidak beranekaragam Indeks kemerataan (evenness) (Odum, 1971;

Prince et al., 1997) ditentukan dengan menggunakan rumus:
Keterangan:

$$
\mathrm{E}=\mathrm{H}^{\prime} / \operatorname{Ln}(\mathbf{S})
$$

$\mathrm{E}=$ indeks kemerataan (nilai antara 0-1)

$\mathrm{H}^{\prime}$ = indeks keanekaragaman Shannon - Wiener

$S=$ jumlah jenis (dalam hal ini famili)

Kriteria indeks kemerataan :

$\mathrm{E}<0,5$ : Kemerataan tinggi(penyebaran jumlah individu tiap jenis merata, atau tidak ada yang mendominasi)

$\mathrm{E}>0,5$ : dominansi tinggi (ada yang mendominansi) Kekayaan jenis ditentukan dengan rumus menurut Margalef (Ludwig \& Reynold 1988):

$$
\mathrm{R}=(\mathrm{s}-1) / \operatorname{Ln} \mathrm{N}
$$

Keterangan:

$\mathrm{R}=$ = Indeks kekayaan jenis

$\mathrm{s} \quad=$ Jumlah jenis serangga

$\mathrm{N} \quad=$ Jumlah total individu serangga

Ln = Logaritma natural

Nilai R berkisar antara :

$\mathrm{R} \leq 3,5$ : Kekayaan Rendah

$3,5<\mathrm{R} \leq 5 \quad$ : Kekayaan Sedang

$\mathrm{R}>5 \quad$ : Kekayaan Tinggi

\section{HASIL DAN PEMBAHASAN}

Kelimpahan arthropoda permukaan tanah di sawah padi hitam berpupuk organik

Hasil penelitian menunjukkan bahwa arthropoda permukaan tanah yang diperoleh dan teridentifikasi yaitu Famili Carabidae, Curculionidae, Staphylinidae, Formicidae, Acrididae, Gryllidae, Gryllotalpidae, Nepidae, dan Lycosidae.

Tabel 1. Jenis ordo, famili dan jumlah individu arthropoda permukaan tanah pada beberapa perlakuan pupuk

\begin{tabular}{|c|c|c|c|c|c|c|}
\hline \multirow[b]{2}{*}{ Ordo } & \multirow[b]{2}{*}{ Famili } & \multicolumn{5}{|c|}{ Perlakuan } \\
\hline & & A & B & $\begin{array}{c}\mathrm{C} \\
\text { (individu) }\end{array}$ & $\mathrm{D}$ & E \\
\hline \multirow{3}{*}{ Coleoptera } & Carabidae & 117 & 142 & 160 & 102 & 93 \\
\hline & Curculionidae & 7 & 9 & 6 & 21 & 15 \\
\hline & Staphylinidae & 0 & 4 & 3 & 0 & 0 \\
\hline \multirow[t]{2}{*}{ Hymenoptera } & Formicidae & 31 & 159 & 98 & 74 & 70 \\
\hline & Acrididae & 16 & 10 & 17 & 9 & 15 \\
\hline \multirow[t]{2}{*}{ Orthoptera } & Gryllidae & 2 & 6 & 3 & 6 & 8 \\
\hline & Gryllotalpidae & 12 & 7 & 6 & 12 & 11 \\
\hline Hemiptera & Nepidae & 3 & 1 & 2 & 3 & 3 \\
\hline Araneae & Lycosidae & 44 & 24 & 40 & 32 & 35 \\
\hline Jumlah & & 232 & 362 & 335 & 259 & 250 \\
\hline
\end{tabular}
di ekosistem sawah padi hitam. 
Jumlah arthropoda permukaan tanah yang diketemukan pada semua perlakuan dalam satu musim tanam yaitu perlakuan kontrol (232 individu), pupuk ampas bungkil mimba (362 individu), kompos gulma siam (335 individu), pupuk kohe sapi (259 individu), dan NPK (250 individu). Lebih lanjut, pada perlakuan pupuk ampas bungkil mimba cenderung memberikan kelimpahan tertinggi pada arhtropoda Famili Carabidae dan Formicidae dibandingkan perlakuan lainya (Tabel 1). Hadi \& Aminah (2015); Witriyanto dkk., (2015) menegaskan bahwa Famili Carabidae dan Formicidae terlihat dominan dan menyukai kondisi habitat pada sawah padi organik.

\section{Komposisi dan peranan arthropoda permukaan tanah Berdasarkan aktivitas makannya, arthropoda permukaan tanah ada yang berperan sebagai}

herbivor, karnivor (predator), saprovor dan fungifor (Suin, 2006) yang berinteraksi dalam jaring makanan. Selain itu, menurut Kilowasid et al., (2014) variasi struktur jaring makanan dipengaruhi faktor biotik yang berkaitan dengan kondisi habitat. Pada penelitian ini, arthropoda permukaan tanah yang ditemukan meliputi arthropoda yang berperan sebagai karnivor (predator) dan herbivor. Berdasarkan Tabel 2, pada perlakuan pupuk ampas bungkil mimba dan kompos gulma siam menunjukkan kelimpahan karnivor tertinggi bila dibandingkan dengan perlakuan lainnya. Selanjutnya, pada semua perlakuan, kelimpahan arthropoda permukaan tanah yang berperan sebagai herbivor tidak berbeda nyata.

Tabel 2. Jumlah individu arthropoda permukaan tanah yang berperan sebagai karnivor dan herbivor pada ekosistem sawah padi hitam.

\begin{tabular}{lcc}
\hline \multirow{2}{*}{ Perlakuan } & \multicolumn{2}{c}{ Jumlah individu arthropoda } \\
\cline { 2 - 3 } & Karnivor & Herbivor \\
\hline Kontrol & $4.23 \pm 0.48 \mathrm{a}$ & $0.60 \pm 0.15 \mathrm{a}$ \\
Ampas Bungkil Mimba & $6.79 \pm 1.17 \mathrm{~b}$ & $0.75 \pm 0.20 \mathrm{a}$ \\
Kompos Gulma Siam & $6.31 \pm 0.87 \mathrm{~b}$ & $0.66 \pm 0.16 \mathrm{a}$ \\
Pupuk kohe sapi & $4.48 \pm 0.65 \mathrm{a}$ & $0.92 \pm 0.27 \mathrm{a}$ \\
NPK & $4.19 \pm 0.40 \mathrm{a}$ & $1.02 \pm 0.30 \mathrm{a}$ \\
\hline
\end{tabular}

Keterangan: $\quad$ Nilai uji Tukey yang diikuti oleh huruf yang sama dalam kolom menunjukkan tidak berbeda nyata pada $\alpha$ 5\%.

Jumlah arthropoda karnivor seluruhnya lebih banyak dibandingkan jumlah arthropoda herbivor di setiap perlakuan. Famili arthropoda yang berperan sebagai karnivor berjumlah enam famili yaitu Carabidae, Curculionidae, Staphylinidae, Formicidae, Nepidae, dan Lycosidae sedangkan famili yang berperan sebagai herbivor sebanyak tiga famili yaitu Acrididae, Gryllidae, dan Gryllotalpidae. Berdasarkan penelitian Dewi et al. (2017), keberadaan jenis arthropoda herbivor dan karnivor yang ada pada persawahan berkaitan erat dengan fase dan performa tanaman serta mangsa yang dibutuhkan untuk perkembangan hidupnya. Selanjutnya, menurut Widiarta dkk., (2007) kelimpahan dan keanekeragaman arhtropoda karnivor relatif tinggi pada sistem budidaya organik. Menurut Jumar (2000) bahwa kelimpahan predator lebih tinggi karena bersifat polifagus yaitu mempunyai banyak jenis makanan, sehingga keberadaannya tidak hanya tergantung dari satu sumber makanan seperti halnya hebivora.

Adapun, total seluruh arthropoda permukaan tanah yang berperan sebagai karnivor memiliki persentase sebesar (16\%) pada perlakuan kontrol, pupuk ampas bungkil mimba (26\%), kompos gulma siam (15\%), pupuk kohe sapi (17\%), dan pupuk NPK sebesar (16\%) (Gambar 1).

Persentase komposisi arthropoda herbivor dari semua perlakuan memperlihatkan bahwa pada perlakuan kontrol diperoleh sebanyak $15 \%$, pupuk ampas bungkil mimba 19\%, kompos gulma siam 17\%, pupuk kohe sapi $23 \%$, dan pada perlakuan pupuk NPK diperoleh arthopoda herbivor sebanyak 26\% (Gambar 1). Lebih lanjut, dapat dilihat juga bahwa jumlah arthropoda karnivor secara umum lebih banyak dibandingkan jumlah arthropoda herbivor. Keberadaan karnivor yang lebih tinggi dibandingkan herbivor pada lahan sawah padi hitam akan menekan populasi arthropoda herbivor sehingga tidak terjadi ledakan hama. Pernyataan ini ditegaskan oleh Mahrub (1998), bahwa keberadaan arthropoda karnivor yang lebih tinggi akan membuat ekosistem pada lahan padi menjadi lebih stabil. Sedangkan, pada perlakuan ampas bungkil mimba diketahui bahwa jumlah arthropoda tanah herbivor lebih sedikit dibadingkan perlakuan lainnya. Menurut 
Schmutterer (1990) mimba memiliki dua peran yaitu sebagai pupuk dan pestisida. Lebih lanjut Painter (1951) menyatakan bahwa tanaman memiliki kemampuan untuk menginduksi ketahanan untuk menghindari serangan serangga herbivor yang dapat muncul melalui input bahan-bahan organik yang diberikan pada pertanaman. Diduga ampas bungkil mimba memiliki kemampuan tersebut.

\section{Arthropoda Karnivor}

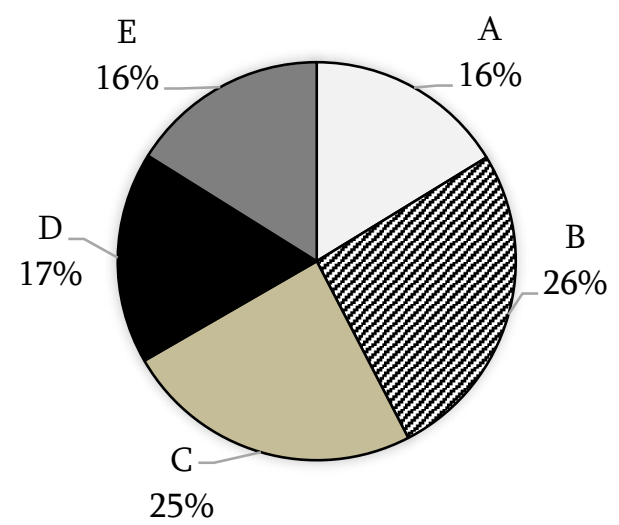

(a)

\section{Arthropoda Herbivor}

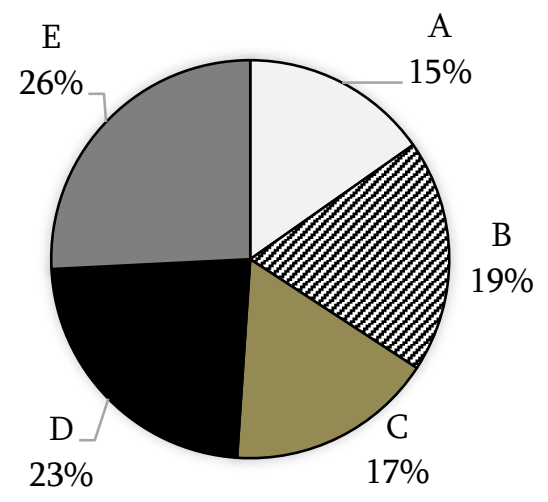

(b)

Gambar 1. Komposisi arthropoda permukaan tanah (a) karnivor dan (b) herbivor pada sawah padi hitam. Keterangan : A = Kontrol, B = Pupuk Ampas Bungkil Mimba, C = Kompos Gulma Siam, D = Pupuk Kohe Sapi dan E = Pupuk NPK

\section{Keanekaragaman arthropoda permukaan tanah}

Berdasarkan analisis pada Tabel 3, data arthropoda permukaan tanah yang diperoleh menunjukkan nilai indeks keanekargaman $\left(\mathrm{H}^{\prime}\right)$ pada perlakuan kontrol sebesar 1,470; pupuk ampas bungkil mimba sebesar 1,310; kompos gulma siam sebesar 1,377; pupuk kohe sapi sebesar 1,585; dan NPK sebesar 1,638. Berdasarkan kriteria indeks keanekaragaman $\left(\mathrm{H}^{\prime}\right)$ maka pupuk ampas bungkil mimba dan perlakuan lainnya memiliki tingkat keanekaragaman yang masuk dalam kategori sedang. Fitriana (2006) menegaskan bahwa apabila indeks keanekaragaman termasuk dalam kategori sedang maka keberadaan jenis arthropoda cukup beragam dan seimbang.

Lebih lanjut, nilai indeks dominansi (C) menunjukkan bahwa pada semua perlakuan memperoleh nilai indeks sebesar $\mathrm{C}>0,5$ artinya terdapat spesies yang mendominansi (Tabel 3). Namun, terlihat bahwa pada pada perlakuan pupuk ampas bungkil mimba cenderung memberikan nilai indeks dominansi yang lebih rendah dibandingkan perlakuan lainnya. Merujuk pada adanya dominansi dari jenis tertentu yaitu Famili Carabidae dan Formicidae, Herlinda dkk. (2014) menegaskan bahwa Famili Carabidae dan Formicidae seringkali menjadi jenis serangga yang dominan pada pertanaman padi. Menurut Witriyanto dkk. (2015) juga menyatakan bahwa melimpahnya Famili Formicidae disebabkan family tersebut merupakan musuh alami atau arthropoda karnivor yang bersifat polifag. Penelitian Sabarudin et al., (2013) juga menegaskan bahwa Coleoptera dan Hymenoptera (Formicidae) merupakan ordo dominan dari arthropoda permukaan tanah pada pertanaman tumpang sari kacang hijau dan jagung dengan penggunaan kompos gulma siam.

Selanjutnya nilai indeks kemerataan (E) pada perlakuan kontrol sebesar $(0,707)$, pupuk ampas bungkil mimba $(0,596)$, kompos gulma siam $(0,627)$, pupuk kohe sapi $(0,762)$, dan NPK $(0,788)$. Pada semua perlakuan, indeks kemerataan (E) nilainya tidak adanya yang hampir mendekati satu. Menurut Magurran (1988) rendahnya nilai kemerataan disebabkan karena adanya spesies dari arthropoda yang mendominansi. Hal berkaitan dengan hasil indeks dominansi (C) yang lebih besar dari 0,5. Walaupun, berdasarkan Tabel 4, terlihat bahwa nilai indeks kemerataan (E) pada perlakuan pupuk ampas bungkil mimba menunjukkan nilai yang lebih rendah sehingga dapat dinyatakan lebih beragam dan merata komposisi jenis yang ada pada petak perlakuan tersebut.

Adapun berdasarkan indeks kekayaan (R) pada perlakuan kontrol sebesar $(1,285)$, pupuk ampas bungkil mimba $(1,376)$, kompos gulma siam $(1,358)$, 
pupuk kohe sapi $(1,260)$, dan NPK $(1,268)$. Seluruh perlakuan mempunyai nilai indeks kekayaan yang tergolong rendah. Hal ini sesuai kriteria indeks kekayaaan menurut Magurran (1998) bahwa nilai $R<$ 3,5 tergolong rendah. Namun apabila dilihat pada Tabel 4, perlakuan pupuk ampas bungkil mimba memberikan kecenderungan nilai indeks kemerataan lebih tinggi bila dibandingkan dengan perlakuan lainnya. Oleh karena itu, berdasarkan pemaparan menunjukkan bahwa pengaruh pupuk ampas bungkil mimba dan gulma siam meningkatkan kelimpahan, keanekaragaman dan komposisi arthopoda permukaan tanah pada ekosistem padi hitam.

Tabel 4. Jumlah ordo, jumlah jenis famili, jumlah individu, nilai indeks keanekaragaman ( $\left.\mathrm{H}^{\prime}\right)$, indeks dominansi (C), indeks kemerataan (E) dan indeks kekayaan (R).

\begin{tabular}{lccccc}
\hline \multirow{2}{*}{ Keterangan } & \multicolumn{5}{c}{ Perlakuan } \\
\cline { 2 - 6 } & $\mathrm{A}$ & $\mathrm{B}$ & $\mathrm{C}$ & $\mathrm{D}$ & $\mathrm{E}$ \\
\hline Jumlah Ordo & 5 & 5 & 5 & 5 & 5 \\
Jumlah Famili & 8 & 9 & 9 & 8 & 8 \\
Jumlah Individu & 232 & 362 & 335 & 259 & 250 \\
Indeks Keanekaragaman (H') & 1,470 & 1,310 & 1,377 & 1,585 & 1,638 \\
Indeks Dominansi (C) & 0,683 & 0,647 & 0,669 & 0,737 & 0,753 \\
Indeks Kemerataan (E) & 0,707 & 0,596 & 0,627 & 0,762 & 0,788 \\
Indeks Kekayaan (R) & 1,285 & 1,376 & 1,358 & 1,260 & 1,268 \\
\hline Keterangan: A = kontrol, B = pupuk ampas bungkil mimba, C = kompos gulma siam, D = pupuk kohe sapi, dan E = pupuk NPK
\end{tabular}

Tabel 5. Jumlah arthropoda permukaan tanah pada fase vegetatif dan generatif tanaman padi hitam berpupuk organik.

\begin{tabular}{lrc}
\hline Perlakuan & Fase vegetatif & Fase generatif \\
\hline Kontrol & $6.03 \pm 0.78 \mathrm{~b}$ & $2.83 \pm 0.41 \mathrm{~b}$ \\
Ampas Bungkil Mimba & $10.16 \pm 1.68 \mathrm{a}$ & $3.17 \pm 0.49 \mathrm{~b}$ \\
Kompos Gulma Siam & $9.37 \pm 1.21 \mathrm{a}$ & $3.00 \pm 0.46 \mathrm{~b}$ \\
Pupuk kohe sapi & $5.87 \pm 0.89 \mathrm{~b}$ & $4.61 \pm 0.75 \mathrm{a}$ \\
NPK & $6.37 \pm 0.68 \mathrm{~b}$ & $3.28 \pm 0.52 \mathrm{~b}$ \\
\hline
\end{tabular}

Keterangan: $\quad$ Nilai uji Tukey yang diikuti oleh huruf yang sama dalam kolom menunjukkan tidak berbeda nyata pada $\alpha$ 5\%.

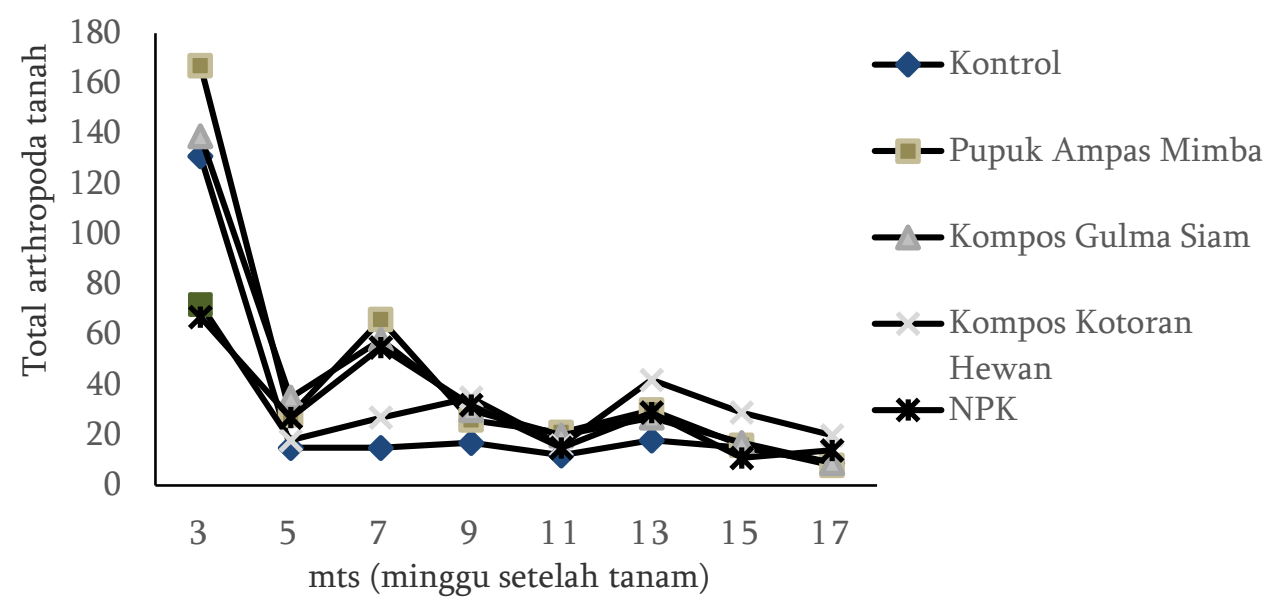

Gambar 2. Total individu arthropoda permukaan tanah pada fase vegetatif dan generatif pada ekosistem padi hitam berpupuk organik.

Keberadaan arthropoda permukaan tanah pada fase vegetatif dan generatif tanaman padi hitam berpupuk organik
Jumlah arthropoda permukaan tanah yang berperan sebagai karnivor dan herbivor pada fase vegetatif dan fase generatif tanaman padi hitam dapat dilihat pada Tabel 5. Pada fase vegetatif, jumlah 
arthropoda tanah tertinggi pada perlakuan pupuk ampas bungkil mimba walaupun pada fase generatif tidak menunjukkan kecenderungan yang sama. Berdasarkan Tabel 5, terlihat bahwa saat fase vegetatif, kelimpahan arthropoda permukaan tanah pada perlakuan pupuk ampas bungkil mimba lebih tinggi dibandingkan dengan perlakuan lainnya. Hal ini menunjukkan bahwa ketertarikan arthropoda permukaan tanah pada petak perlakuan pupuk ampas bungkil mimba dipengaruhi oleh performa tanaman dan bahan organik. Performa tanaman yang baik dipengaruhi oleh bahan organik yang digunakan sehingga memberikan suplai nutrisi yang baik bagi pertanaman dan menstimulasi aktivitas arthropoda. Namun ketika tanaman telah memasuki fase generatif, jumlah arthropoda pada semua perlakuan menurun. Kondisi tersebut sesuai dengan pernyataan (Untung, 1996; Widiarta dkk., 2007) bahwa keberadaan arthropoda pada pertanaman dipengaruhi oleh fase pertumbuhan tanaman yang berkaitan dengan sumber pakan dan kondisi habitatnya. Selain itu, keberadaan arthropoda tanah dipengaruhi oleh bahan organik sebagai sumber pakan dan mampu meningkatkan kompleksitas rantai makanan pada ekosistem tanah (Witriyanto dkk., 2015).

Pada Gambar 2, menunjukkan fluktuasi jumlah arthropoda tanah pada fase vegetatif dan fase generatif dari setiap pengamatan selama musim tanam. Pada pengamatan 3-7 MST (minggu setelah tanam), perlakuan pupuk ampas bungkil mimba cenderung memberikan kelimpahan tertinggi bila dibandingkan dengan perlakuan lainnya. Namun selanjutnya pada semua perlakuan mengalami penurunan jumlah arthropoda tanah sampai pada akhir pengamatan (17 MST). Fenomena tersebut didukung oleh Araunjo et al., (2018) bahwa ketersediaan bahan organik pada tanah dapat meningkatkan keberadaan arthropoda karena bahan organik menjadi sumber nutrisi bagi tanah untuk meningkatkan performa dan pertumbuhan tanaman. Menurut Ajidirman (2006), terdapat hubungan antara makrofauna dan bahan organik, kondisi fisik tanah, dan pertumbuhan tanaman, Sugiyarto (2000) juga menegaskan bahwa keberadaan bahan organik dapat meningkatkan kondisi mikrohabitat sehingga mendukung keberlangsungan hidup arthropoda tanah.

\section{SIMPULAN}

Simpulan dari penelitian ini adalah:
1. Aplikasi pupuk ampas bungki mimba dan gulma siam dapat meningkatkan kelimpahan arthropoda permukaan tanah pada ekosistem sawah padi hitam sebanyak (362 dan 335 individu) jika dibandingkan dengan pelakuan kontrol, pupuk kohe sapi dan NPK sebanyak (232, 259, dan 250 individu).

2. Nilai indeks keanekaragaman arthropoda permukaan tanah pada perlakuan (kontrol, pupuk ampas bungkil mimba, kompos gulma siam, pupuk kohe sapi dan NPK) sebesar (1.470;1.310; $1.377 ; 1.585$ dan 1.638) yang termasuk dalam kategori sedang

3. Perlakuan pupuk ampas bungkil mimba dan kompos gulma siam memperlihatkan kelimpahan karnivor tertinggi, namun tidak berbeda nyata pada kelimpahan herbivor.

4. Perlakuan pupuk ampas bungkil mimba dan kompos gulma siam memperlihatkan kelimpahan arthropoda permukaan tanah pada fase vegetatif lebih tinggi bila dibandingkan dengan perlakuan lainnya, namun pada fase generatif yang memberikan kelimpahan arthropoda permukaan tanah tertinggi adalah perlakuan kohe sapi.

\section{DAFTAR PUSTAKA}

Ajidirman. 2006. Study of the restoration of the corganic soil and its relationship with the physical fertility under cover vegetation of palm. Jurnal Agronomi. 10(2): 81-84.

Adriyani, R. 2006. Usaha pengendalian pencemaran lingkungan akibat penggunaan pestisida pertanian. Jurnal Kesehatan Lingkungan 3 (1): 95-106.

Arief, A. 2001. Hutan dan Kehutanan. Jakarta. Kanisius. 177 p.

Bolton B. 1994. Identication guide to the ant genera of te world. Cambridge: Harvad. University Press.

Bonkowski, M, B Griffiths, dan C Scrimgeoure. 2000. Substrate heterogenity and microfauna in soil organic 'hotspots' as determinants of nitrogen capture and growth of ryegrass. Appl. Soil Ecology. 14: 37-53.

Borror DJ, CA Triplehorn, dan NF Johnson.1996. Introduction of Insect Study. Seventh Edition. Gadjah Mada University Press: Yogyakarta.

Dewi, VK, S Sato, and H Yasuda. 2017. Effects of a mud snail Cipangopaludina Chinensis Laeta (Architaenioglossa: Viviparidae) on the 
abundance of terrestrial arthropods through rice plant development in a paddy field. J. Applied Entomology and Zoology. 52 (1): 97106.
Lestari, dan A Puji. 2009. pengembangan pertanian berkelanjutan melalui substitusi pupuk anorganik dengan pupuk organik. Jurnal Agronomi. 13 (1): 38-44.

Dewi, VK, NS Putra, B Purwanto, S Hartati, dan S SariLudwig, JA, and JF Reynolds. 1988. Statistical 2018. Aplikasi kompos gulma siam chromolaena odorata terhadap sifat kimia tanah dan performa tanaman cabai. Soilrens.16 (1): 66-72.

Fitriana, YR. 2006. Keanekaragaman dan kelimpahan makrozoobentis di hutan mangrove hasil rehabilitasi taman hutan raya Ngurah Rai Bali. Biodiversitas. 7 (1): 67-72.

Gardi, C, dan S Jeffrey. 2009. Soil Biodiversity. European Commission Joint Research Centre, Institute for Enviromental and Sustainability, Land Management and Natural Hazards Unit.

Hadi, M., R. C. H. Soesilohadi, F. X. Wagiman, dan Y. R. Suhardjono. 2015. Keragaman Arthropoda Tanah pada Ekosistem Sawah Organik dan Sawah Anorganik. Prosiding Seminar Nasional Masyarakat Biodiv Indon. 1(7): 1577-158.

Herlinda, S, A Rauf, S Sosromarsono, U Kartosuwondo, Siswadi, dan P Hidayat. 2014. Arthropoda musuh alami penghuni ekosistem persawahan di daerah Cianjur, Jawa Barat. J. Entomol. 1(1): 9-15.

Jumar. 2000. Entomologi Pertanian. Penerbit Rieneka Cipta. Jakarta

Jeffrey S, C Gardi, A Jones, L Montanarella, L Marmo, L Miko, K Ritz, G Peres, J Rombke, dan var der Putten WH. 2011. European atlas of soil biodiversity. European Commission, Publication Office of the European Union.

Kardinan, A. 2011. Penggunaan pestisida nabati sebagai kearifan lokal dalam pengendalian hama tanaman menuju sistem pertanian organik. Pengembangan Inovasi Pertanian. 4 (4): 262-278.

Kilowasid, LMH, TS Syamsudin, FX Susilo, E Sulistyawati and H Syaf. 2013. Characteristics of soil fauna communities and habitat in small-holder cocoa plantation in South Konawe. J Trop Soils. 18 (2): 149159.

Krebs CJ. 1989. Ecological methodology. Harper and Row Publisher. New York. 654 pp

Kristamtini dan H Purwaningsih. 2009. Potensi pengembangan beras merah sebagai plasma nutfah Yogyakarta. J. Litbang Pertanian. 28(3):88-95. ecology. A primer on method and computing. John Wiley and Sons, Inc. New York.

Magurran, AE. 1988. Ecologycal diversity and its measurement. New Jersey: Pricenton University Press.

Mayrowani, H. 2012. Pengembangan pertanian organik di Indonesia. Forum Penelitian Agro Ekonomi. 30(2): 91 - 108.

Nandini, R. 2013. Pemanfaatan hidrogel dan pupuk organik sebagai pembenah tanah dalam rehabilitasi lahan kritis berbasis mimba (Azadirachta indica A.Juss). Balai Penelitian Teknologi Hasil Hutan Bukan Kayu (BPTHHB).

Nurindah, DA dan Sujak. 2012. Efektivitas dan kompatibilitas ekstrak biji mimba untuk mengendalikan kompleks penggerek buah kapas. Bulletin Littro. 23 (1): 48-60.

Odum, E. 1993. Dasar-dasar ekologi. Penerjemah: Tjahyono Saminginan. Gadjah Mada University Press. Yogyakarta.

Painter, R.H. 1951. Insect resistance in crop plant. Macmilllan. New York.

Pimentel, D, H Acquay, M Biltonen, P Rice, M Silva, J Nelson, V Lipner, S Giordano, A Horowitz, and M D'Amore. 1992. Environmental and economic costs of pesticide use. BioScience. 42: $750-760$.

Prince, PW, CE Bouton, P Gross, BA McPheron, JN Thompson, and AE Weis. 1997. Interaction among three trophic level: Influence of plants on interactions between herbivores and natural enemies. Annual Review of Ecology and Systematic. 11: 41-65.

Sabaruddin, L., L.M.H. Kilowasid and H. Syaf (2013). Effect of "komba-komba" pruning compost and planting time of mungbean in intercropping with maize on yield and soil fauna. Agrivita. 35(1):13-21.

Samudra, BF, M Izzati, dan H Purnaweni. 2013. Kelimpahan dan keanekaragaman arthropoda tanah di lahan sayuran organik "urban farming". Prosiding Seminar Nasional Pengelolaan Sumberdaya Alam dan Lingkungan 1: 1-2.

Schmutterer, H. 1990. Properties and potential of natural pesticides from neem tree, 
Azadirachta indica. Ann. Rev. Entomol. 35:271-291.

Setiawan, B, dan Nandini. 2013. Membuat Pupuk secara Cepat. Kanisius: Jakarta.

Sofia D. 2001. Pengaruh Pestisida dalam Lingkungan Pertanian. Digital Library. Fakultas Pertanian Universitas Sumatra Utara, Medan.

Suharjo dan Aeny. 2011. Eksplorasi Potensi Gulma Siam (Chromolaena odorata) sebagai biofungisida pengendali Phytophthora palmivora yang diisolasi dari buah kakao. J. HPT Tropika. 11 (2): 201 - 209.

Suin, M. 2006. Ekologi Hewan Tanah. Bumi Aksara. Jakarta.

Sugiyarto. 2000. The diversity of soil macrofauna in different age stands of sengon in Kediri Regency Jatirejo. Biodiversity. 1 (2):47-53.

Widiarta, IN, K Dede, dan Suprohanto. 2007. Keragaman arthropoda pada padi sawah dengan pengelolaan tanaman terpadu. Jurnal HPT Tropika. 6 (2): 61-68.

Widowati, LR. 2009. Peranan pupuk organik terhadap efisiensi pemupukan dan tingkat kebutuhannya untuk tanaman sayuran pada tanah inseptisols Ciherang,Bogor. Jurnal Tanah Tropika. 14:221-228.

Witriyanto, R, H Mochamad, dan R Rully. 2015. Keanekaragaman makro arthropoda tanah di lahan persawahan padi organik dan anorganik, Desa Bakalrejo Kecamatan Susukan Kabupaten Semarang. Bioma. 17(1):21-26

Zachariades, C, M Day, R Muniappan, and GVP Reddy. 2009. Chromolaena odorata (L.) King and Robinson (Asteraceae). In Biological Control of Tropical Weeds Using arthropods (eds. Muniappan, R., Reddy, G.V.P. \& Raman, A.), pp. 130-162, Cambridge University Press, Cambridge, UK. 